\title{
42
}

\section{The Broken Bar Shutters}

When the bars of the nightclub closed, heavy shutters had to be pulled down. They were old and did not function very well, so there were often near-accidents and the staff were constantly complaining about the risks. In spite of that management refused to have them renovated or replaced. The cost would be astronomical, they said. But when two customers were injured by the shutters, new ones were finally installed. The general manager called a meeting, pointed to the shutters and declared: "Those shutters cost 1000 quid, more than all of you lot are worth. I can replace you lot anytime I wish, but I can't afford those shutters again. Make sure that they're not dropped on the counters.'

The staff who had nagged so much about getting new shutters now pulled them with such force that they soon became useless. 'If the shutters are worth more than me (workers) do you wonder how much exactly we are each worth... down with the shutters...' one of them exclaimed.

(Analoui and Kakabadse, 1989) 